\title{
RHODESIA FIVE YEARS AFTER THE UNILATERAL DECLARATION OF INDEPENDENCE
}

\author{
by ZDENeK ČERvenKa
}

On 11 November 1970, five years had passed since the white minority regime in Rhodesia ${ }^{1}$ had unilaterally declared the country independent of British rule. Harold Wilson, the then Prime Minister of Britain, described the event in the House of Commons as "an illegal act and one ineffective in law". He also said: "This is an act of rebellion against the Crown, and against the Constitution as by law established. Actions taken to give effect to it will be treasonable ${ }^{2}$."

$\mathrm{He}$ ended his statement by calling it a "tragedy affecting a great people, including many thousands who have made their homes there and who are plunged into a maelstrom not of their own making and of millions more who are denied the inalienable human right of self-expression and self-determination ${ }^{3}$."

The British Government, however, strongly opposed the use of force to quell the rebellion of the white minority in Rhodesia, despite the appeals of the Organization of African Unity (OAU) ${ }^{4}$ and indeed of the Security Council ${ }^{5}$ to do so.

At the Commonwealth Prime Ministers' Conference in Lagos in January 1966, Harold Wilson assured his colleagues that economic sanctions imposed on Rhodesia would "bring the rebellion to an end within a matter of weeks rather than months". His confidence was fully shared by President Kaunda, of Zambia, who said on 14 January 1966, with reference to the Commonwealth Conference then scheduled for July 1970: "I do not for one moment believe that Smith will be in power then ${ }^{7}$." How is it possible that Rhodesia, whose racial policies are second only to those of South Africa, has succeeded in defying the United Kingdom, the United Nations and the Organisation of African Unity for more than 5 years now? The fact of Rhodesia's continuing independent existence is even more astonishing when it is considered that not one single government has so far recognized Rhodesia as a sovereign state. Before examining Rhodesia's position in international law and in the international community of states, it is necessary to go back a little way into the history of Rhodesia.

\footnotetext{
1 "Southern Rhodesia" is the official name, but when "Northern Rhodesia" obtained independence as Zambia in 1964, the "Southern" was dropped from general use, though not immediately. At the time Zambia in 1964, the "Southern" was dropped from general use, though not immediately. At the time
of the Unilateral Declaration of Independenc (UDI) in 1965 and in 1966 both the Organization of African Unity and the United Nations continued to refer to it as "Southern Rhodesia", up to about 1968. Since 1965 the Organisation of African Unity has referred to Rhodesia also by the name of "Zimbabwe", which is to be the name of Rhodesia when it attains independence on the basis of "one man one vote". The name "Zimbabwe" originally denoted the burial ground of the chiefs of the Karanga nation who were believed to have arrived in Rhodesia about the year 1325, (cf. Ransford, O.: The Rulers of Rhodesia, from the Earliest Times to the Referendum, London; 1968, p. 24).

2 The Times, London, 1965, November 11.

3 The Times, London, 1965, November 11.

4 The Council of Ministers of the OAU, meeting at Addis Ababa in its sixth extraordinary session from 3 to 5 December 1965, issued an ultimatum to the United Kingdom that, if "it does not crush the rebellion and restore law and order, and thereby prepare the way for majority rule in Southern Rhodesia by 15 December 1965, the Member States of the OAU shall sever diplomatic relations on that date with the United Kingdom" (ECM/Res. 13/VI).

$5 \mathrm{At}$ its 1265th meeting on 20 November 1965, the Security Council adopted a resolution (217[1965]) by 10 votes to none with 1 abstention (France), calling upon the Government of the United Kingdom to "quell this rebellion" and "to take all other appropriate measures which would prove effective in eliminating the authority of the usurpers and in bringing the minority régime in Southern Rhodesia to an immediate end".

6 The Commonwealth Prime Ministers' Meeting, Final Communiqué, quoted by the Ghanaian Times, Accra, January 13, 1966.

7 Times of Zambia, Lusaka 1966, January 14, quoted in the Documentation Service, Nos. 1-2 (1967), London; Africa Research Ltd., 1967, p. 4.
} 


\section{A Brief Description of Rhodesia}

Rhodesia is a land-locked country about $389,361 \mathrm{~km}^{2}$ in extent, about one and a half times the size of the Federal Republic of Germany $\left(247,961 \mathrm{~km}^{2}\right)$. It is bounded on the north and west by Zambia and Botswana, on the south by the Republic of South Africa and on the east by the Portuguese colony of Mozambique. According to the 1969 estimates, Rhodesia's population is about 4,930,000 Africans, 260,000 Europeans ${ }^{8}$. There are unique features in the Rhodesian situation which add to its complexity. First, Rhodesia is on the frontier between "black" and "white" Africa. To the north, Zambia, Malawi, the Congo, and the East African countries are all governed by African governments and, with the exception of Malawi, are committed to the policy of eradicating exactly the type of regime which is at present in power in Rhodesia. To the south is the great bastion of white supremacy based on the policy of apartheid, the Republic of South Africa. On either side of Rhodesia, to the east and the north-west, are the Portuguese territories of Mozambique and Angola, anachronistic reminders of the great European empires of the past. The geographical division is not absolute, for, to the south of Rhodesia, Botswana, Lesotho, and Swaziland are already independent. So far, however, the existence of these three countries has not substantially affected the generalisation that north of the Zambezi is "black" and south of the Limpopo is "white", at least certainly not in terms of power".

\section{Early History of Rhodesia}

This is how the early days of Rhodesia have been described by a British scholar:

Eighty years ago Rhodesia was known only to the few traders and missionaries who had followed Livingstone. Cecil Rhodes, the Kimberley diamond millionaire who became prime minister of Britain's Cape Colony in 1890, was fascinated by it. A passionate imperialist with grandiose ambitions, he was eager to extend British power around the South African Boer republics to the territory further north, where, it was believed, the mineral riches were great. What is now Southern Rhodesia had been dominated for over fifty years by the Matabele tribe. In 1887, Rhodes's agent, Charles Rudd, signed an agreement with the Matabele chief, Lobengula, that diddled (there is no other word for it) the chief out of all mineral rights in his domains in exchange for rifles, ammunition and $£ 100 \mathrm{a}$ month. These rights were taken by Rhodes's British South Africa Company, which in 1889 received a royal charter. The Company's "Pioneer Column“ occupied Mashonaland in 1890. Three years later Rhodes's men picked a quarrel with the Matabele, who resisted and were crushed ${ }^{10}$.

In a very real sense, modern Rhodesia is the creature of Lord Salisbury's late Victorian England and of the old Cape Colony, whose Prime Minister in 1890 was Cecil John Rhodes. It was he who organised the Pioneer Column, which marched northward into the unchartered wilds of Mashonaland and Matabeland, where Lobengula ruled. The Pioneer Column was led by a young man called Frank

\footnotetext{
8 Rhodesia, Summaries of economic data, E. C. A., Addis Ababa, 1970, (070-693) p. 1. The study states growth rate since $1960=3.3$ per cent per annum. The Rhodesian statistics tend to be rather unreliable, as pointed out by Colin Legum in his article "UDI-Five Years On", in the New World, London, 1970 (November). In December 1968 official statistics put white Rhodesian claims at 237,000 and the claims were that they were increasing by about 7,000 a year. Yet, in March 1969, the published statistics showed a total white population of 228,000 . At the same time the black Rhodesians had gone up to $4,817,950$, from $3,618,150$ in 1962 . It has also been officially admitted that an earlier "mistake" had been made omitting 220,000 Africans - a mistake involving a figure almost as large as the total white population.

9 Barber, K. J.: Rhodesia, the Road to Rebellion, London, 1967, p. 2.

10 Rogaly, J.: Rhodesia, Britain's Deep South, London, 1962, p. 9.
} 
Johnson, who received $\$ 87,000$ from Cecil Rhodes to finance the expedition. It consisted of 200 picked men (more than 2,000 applied), accompanied by a police force of 400 men.

By design, and not by accident, the Pioneer Column was composed of South Africans as well as Britons. The political aim, as frankly outlined by Rhodes, demanded a substantial number of men from Natal and the Cape, so that if things went wrong and outside help were needed, the electorate of these two colonies would join in the clamour for Britain to intervene. Again, at Rhodes's specific direction, the South Africans were "men of both the races", so that the Afrikaners of the Cape Colony would have a stake in the new nation from the start.

The object was to create a new "white Dominion" in the heart of Africa, in a territory whose climate, mineral resources and potential agricultural development were known to favour white settlement. Each man set off from Kimberley for the march (of more than 400 miles) knowing that at the end of the trail there awaited him a considerable bounty, to be given him as of right - not less than fifteen gold claims and a farm of 3,000 acres. The wandering bands of Matabele and Mashona peoples he looked upon as his potential labour force.

It is a vital, though now forgotten fact, that the whole expedition was not a venture of Britain as an Imperial Power, but essentially a private venture undertaken through South African initiative. Rhodes was the instigator, and the man who paid the bills ${ }^{11}$.

The operations of the Pioneer Column have become a glorified chapter of Rhodesia's history, which, according to contemporary interpretations emanating from Salisbury, "brought the African people from the primitive darkness into the light of civilization ${ }^{12}$ ".

The Royal Charter for the British South Africa Company authorized Cecil Rhodes to settle and administer an area of unspecified extent northward, beginning "immediately to the north of British Bechuanaland and to the north and west of the South African Republic and to the west of the Portuguese Dominions ${ }^{13}$ ".

This was, of course, contrary to the Rudd Concessions, which granted no rights to settlement or administration ${ }^{14}$. As it turned out, however, it was the switch from mining and prospecting to agriculture which became the decisive factor that shaped the policies of the Company. Its rule lasted nearly 35 years. The most important thing which happened in Rhodesia between 1896 and 1900 was the building of the railway. The first railway line reached Bulawayo in 1897. The next important line to be completed was that between Beira and Umtali. The first train from Beira reached Umtali in $1898^{15}$. After 1900 the Company was forced to cease relying on gold-mining, which did not yield the expected profits, into a policy of promoting agriculture development. The Company was driven farther and

11 Keatly, P.: The Politics of Partnership: The Federation of Rhodesia and Nyasaland, London, 1963, pp. $26-27$.

12 Information paper No. 1 on Land Apportionment in Rhodesia, published by the Rhodesian Ministry of Information Service, 1965 , p. 2.

This is how this era is being described in a history textbook (Grade 5) used in Rhodesian schools: Today 80 years after the arrival of the Column, there are great changes. There are roads where there were none before, there are hospitals, schools even a University. Crops are growing where none would grow before, there is peace where before there had only been killing, and health where there had only been disease. Sometimes things seem to happen very slowly and there seems a great deal still to do - but just imagine what it must have been like to live in Rhodesia only eighty years ago. (Salt, B.: Ventures into History, Rhodesia, (Grade 5), Salisbury; The College Press, 1969.

13 Charter of the British South Africa Company, October 29, 1889, C. 8773.

14 Leys, C.: European Politics in Southern Rhodesia, Oxford, 1959, p. 5.

15 In June, 1891, Britain and Portugal signed an agreement that Portugal should keep the coast line from Limpopo to the Zambesi, and also that it should have the country inland as far as Umtali. In return the Portuguese were to give up any claim to Mashonaland, Manicaland and a piece of land which lay between the eastern mountains of the Sabi River. The port of Beira was opened for trade from Rhodesia and a railway line was later built from Beira to Salisbury. 
farther into dependence on the settlers, who exacted a steadily increasing measure of political power as the price of their co-operation. Ultimately, the Company was ousted altogether from political control and settlers' rule was substituted in its place. In this process, the institutional framework established by the Company was filled out and elaborated in a way which reflected the growing domination of the African population by the settler community ${ }^{16}$.

In 1914, when the original Charter had to be renewed, the Supplemental Charter provided that the Crown would grant Responsible Government if the settlers expressed an unmistakable desire for it and could demonstrate that the country was in a suitable condition financially and in other respects. From this time onward, the settlers were steadily mounting pressure to take advantage of this clause.

On 27 October 1922, the question of the country's constitutional future was put to the electors, that is, to the white settlers ${ }^{17}$.

The voters were asked to choose between "responsible internal government as a Crown Colony" and integration into the Union of South Africa, which had come into being as a British Dominion in 1910. The electors choose self-government by 8,744 votes to 5,98918 .

On 1 September 1923, the administrative control of the Company was brought to an end by the Southern Rhodesia Constitution Letters Patent. Rhodesia was annexed to the British Crown and its Legislative Assembly was granted powers of self-government ${ }^{19}$.

\section{Constitutional Development in Rhodesia}

\section{(a) The Constitution of 1923}

The first Constitution of Rhodesia granted by the Southern Rhodesia Constitution Letters Patent of 1923 provided for a legislative Assembly of 30 members, all elected and a cabinet system of "responsible government functioning at the pleasure of the legislature", enjoying largely unlimited sovereignty in domestic matters and authorized to make laws for the "peace order and good government of Southern Rhodesia". It was also empowered to amend, by a two-thirds majority, the Constitutional Letters Patent, excepting those sections bearing on native administration, native rights and certain powers of the Governor. The British Government reserved the right to veto any Rhodesian legislature that adversely affected the interests of the African inhabitants, ran counter to Britain's international obligations or affected the remaining rights of the British South

\footnotetext{
16 Leys, op. cit. p. 8.

17 From 1898 the vote was given to all men who were British subjects (or who made a declaration of allegiance), over 21 and literate enough to fill in the particulars on the application form, provided they had an income of $£ 50$ per annum or occupied property or buildings worth $£ 75$ or owned a mining claim. In 1912 the income qualification was raised to $£ 100$ and the property qualification was raised to $£ 160$. In 1917 it was officially stated that, if these limits were in danger of being was raised to 160 . In 1917 it was officially stated that, if these limits were in danger of being the fact that throughout this period the wage of an African was around $\$ 3$ a month, the result was that the electoral roll was open to Europeans only, although all races were theoretically eligible.

18 For details of the referendum, see, Randsford, O.: The Rulers of Rhodesia, London, 1968, pp. 306-318.

19 "Southern Rhodesia: Despatch to the High Commissioner of South Africa transmitting draft letters patent providing for the Constitution of responsible government in the Colony of Southern Rhodesia and other draft instruments connected therewith." London; Cmd. 1573, 1922.
} 
Africa Company ${ }^{20}$. From the legal point of view the 1923 Constitution does not manifest an absolute prohibition. Its descretionary element is patent in its terms. Unequal protection is not prohibited; it may merely be subject to prohibition. The discretion in each instance is exercised not by the judiciary but first by the Governor, who must decide whether the legislation is in fact unequal in its application to the African, and, second, by the Dominions Secretary, on behalf of the British Government, who makes his decisions and is uninhibited in the exercise of his powers by any rule of law nor by any legal standard ${ }^{21}$. The British Government, however, never once interfered with the Southern Rhodesian legislation, despite the fact that some of it was blatantly discriminatory against the Africans. One crucial piece of legislation which the British Government might well have vetoed - since it had declared in 1923 that in the colonial situation the native interest must be paramount - was the Land Apportionment Act of 1930. This Act was promoted as protecting African rights in the land set aside for them, while giving all other land to the whites and the Crown. In fact, the new law gave the tiny white community a hugely disproportionate share of the land and totally precluded Africans from owning town property ${ }^{22}$. Under the Land Apportionment Act of 1930 the Europeans, 50,070 in number ${ }^{23}$, were allotted 44,060,000 acres, and the Africans, numbering 1,081,000 were allotted only 21,600,000 acres (less than half). In 1941 there was a further expansion of the African Reserves'24, which increased their total area to approximately 30,000,000 acres, but by then the African population had reached 1,425,000, as against 69,330 Europeans. Despite the racial character of the Land Apportionment Act, which laid the foundations of the policy of "two pyramids25", the British Government never intervened at this or any other later stage of development of the discriminatory policy of the Rhodesian Government ${ }^{26}$.

20 These limitations were embodied in Section 28 of the Letters Patent, which read as follows:

(a) Section 28 provides that "any law, save in respect of the supply of arms, ammunition or liquor to natives, whereby natives may be subjected or made liable to any conditions, disabilities, or restrictions to which persons of European descent are not also subjected or made liable", must be reserved for the signification of the pleasure of the Crown, unless the Governor, prior to its passing, shall have obtained instructions upon such proposed legislation through the Secretary of State, or unless it contains a clause suspending its operation until such pleasure has been signified.

(b) Section 40 provides that no such discriminative conditions shall be imposed, without the previous consent of the Secretary of State, by any proclamation, regulation or other instrument issued under the provisions of any law, unless they have been explicitly prescribed, defined and limited in such law.

(c) Certain supervisory and other powers in regard to native administration were vested in the (c) Certain supervisory and other powers in regard to native administration were vested in the
High Commissioner for South Africa... O One important provision in the Letters Patent vested the Native Reserves in him (Bledisloe Report; Cmnd, 5949, 1939).

21 Frack, T.: Race and Nationalism, London, 1960, p. 19.

22 The Land Apportionment Act of 1930 was passed on the basis of the report of a Land Commission under the chairmanship of Sir Morris Carter, which found that "however desirable it may be that members of the two races should live together side by side with equal rights as regards the holding of land, we are convinced that in practice, probably for generations to come, such policy is not practicable or in the best interest of the two races and that until the Native has advanced very much practicable or in the best interest of the two races and that until the Native has advanced very much
further on the paths of civilization it is better that points of contact in this respect between the two races should be reduced" (Carter Commission Report, Salisbury, Government Printer, 1926, p. 63).

23 Population Growth, 1901-56 published in the Official Yearbook, monthly digest of statistics and quoted by C. Leys, opus. cit. p. 14.

24 The Land Apportionment Act of 1941 also provided for the establishment of townships for Africans.

25 "This policy envisaged a predominantly white and a predominantly black pyramid standing side by side. At the base of the white pyramid was a layer of unskilled black labour, while the apex of the black pyramid contained Europeans; native commissioners, missionaries, and the like. Within the black pyramid detailed control lay with the native commissioners, who would, helped by the chiefs, exercise a paternal administration". (Barber, op. cit., p. 8).

26 Another piece of legislation which called for intervention by the metropolitan power was the Land Husbandry Act of 1951, which purports to revolutionize African agriculture by promoting good farming methods, like continuous cultivation of the soil and destocking of cattle, and by encouraging individual
ownership of land. In the words of B. V. Mtshali, "the act violated the spirit of communal ownership and assistance and deprived the chiefs of their power over the people, to whom traditionally they allot land and in exchange get loyalty. Moreover, destockings means the reduction of the African's most highly prized possession, cattle, which is a measure of his wealth and status. Finally, when feeling the harsh effects of this law, the Africans in the reserves can with bitterness (and no doubt envy) look across the border at the European farmlands, mostly undeveloped, of ten of better quality but of ten unused" (B. V. Mtshali, Rhodesia: Background to the Conflict, New York, 1967, p. 69). 
The consistently unused constitutional power granted to the British Parliament by Section 28(a) of the 1923 Constitution of Rhodesia gave rise to what has become known as "convention". The essence of the "convention" was defined by Mr. Godber, the delegate of the United Kingdom in the Fourth Committee of the General Assembly, on 25 October, 1962 as follows:

"From the middle of the nineteenth century, however, there had been a convention against Parliament legislating for the self-governing colonies without their consent and the same convention applied to Southern Rhodesia. That convention was now very powerful. From a strictly legal point of view, it was possible for Parliament to revoke the Statute of Westminster (which provided that the United Kingdom Parliament would not legislate for any of the Dominions other than at its request and with its consent) or revoke any of the Acts which, since 1931, has recognized independence of States that had become members of the Commonwealth. Such action was, however, unthinkable in practice. As a distinguished British judge had once stated, the Imperial Parliament could, as a matter of abstract law, repeal or disregard section 4 of the Statute of Westminster but that was theory and had no relation to realities. That fundamental point must be appreciated if the position of the British Government over forty years since Southern Rhodesia had achieved selfgovernment was to be understood."27

Thus, abstention from exercising the right of intervention in Rhodesia's legislation has become "a convention" just as surely and effectively as if the Rhodesian Constitution itself had been amended ${ }^{28}$.

However, this view was contested by the Government of Ghana in its Memorandum submitted to the Security Council on 2 August, 1963, calling the attention of the British Government to a parallel between Malta and Rhodesia ${ }^{20}$.

In practice, the 1923 Constitution left the white Rhodesians very effectively in charge of their own police, army and civil service. Its legislature, consisting entirely of white settlers and elected by a voters roll on which other races were of no influence, operated exactly like the British Parliament with a Cabinet, an opposition and a Prime Minister who regularly attended meetings of the Commonwealth Prime Ministers. There were no British troops on Southern Rhodesia's territory, which was free of all effective British control over its affairs. By virtue of the 1923 Constitution the control passed from London to Salisbury and stayed there too.

\section{(b) The Constitution of 1961}

The 1961 Constitution of Southern Rhodesia ${ }^{30}$ was enacted on December 6, 1961, by the British Government by an Order in Council made under the authority of a British Act of Parliament. It came into effect on 1 November 1962.

27 Records of the Proceedings of the Fourth Committee, 1360th meeting, 25 October, 1962, Doc.

28 A reference to the sacrosanct "convention" was made at a number of occasions. For example on June 29, 1965 the Prime Minister told the Parliament that his Government would adhere to the convention that the British Parliament did not legislate on matters within the legislative competence of the Parliament of Rhodesia (Africa Research Bulletin, Exeter, 1965, Vol. II. No. 6 p. 320). Similar assurance was given by the British Commonwealth Secretary earlier the same year, on March 8, 1965 in the House of Commons. He said: "As far as affairs which are normally conducted internally by the Rhodesian Government by convention is concerned, we have no powers of intervention." (ibid. No. 3. p. 263).

29 In the Memorandum the following point was made: "The Maltese and Southern Rhodesian Constitutions were enacted by Britain by the same process - Letters Patent from the Crown - shortly after each other, the Maltese Constitution in 1921, the Southern Rhodesian in 1923. The legal authorities considered that the two countries had almost exactly the same constitutional status. Nevertheless, in 1936 without the consent of the Maltese Legislature or of any elected Maltese Government, the British Government legislated with regard to Malta so as to provide for the suppression of the Maltese Parliament and the suspension of the Constitution without any regard to convention."

30 British Statutory Instrument No. 2314, 1961. 
The 1961 Constitution differed from that of 1923 in that

(1) The power of veto over dicriminatory legislation and the right to check on the introduction of further discriminatory measures, which, of course, the British Parliament never exercised, was abandoned. It was replaced by a Declaration of Rights, whose object was to ensure that every person in Southern Rhodesia enjoyed the fundamental rights and freedoms of the individual, regardless of race, tribe, place of origin, political opinion, colour or creed. The Declaration, however, was a mere recitation of fundamental principles and it was so widely drawn "that the idea it was going to protect the African population of Southern Rhodesia was very nearly illusory" 31 .

(2) A Constitutional Council was set up which was to examine all Bills - other than money Bills - passed by the Legislative Assembly of Southern Rhodesia before they were presented by the Governor for the Royal consent. The functions of the Constitutional Council were advisory only and in the case of adverse opinion the Legislative Assembly could submit the Bill to the Governor for the Royal assent only upon an affirmative vote of not less than a two-thirds majority of the total members of the Assembly and after a delay of six months a simple majority of the membership only.

(3) A complicated electoral system was devised to ensure that no more than 15 seats out of the 65 seats of the enlarged Legislative Assembly would be filled by Africans, while 50 seats were reserved for the representatives of 223,000 European settlers. As the Constitution could be amended by the vote of any 44 members, it left the legislation, including the amendment of the Constitution, at the discretion of the white settler minority, which could easily command the majority required.

The subordination of Rhodesia to Britain was set forth in the powers of the Governor-General appointed on the advice of the British Government (and the Rhodesian Government), which were restricted to

(a) Bills with respect to certain electoral matters,

(b) bills to which the Constitutional Council objected,

(c) bills to amend the Constitution.

There were other limitations, such as that the Rhodesian Legislature had no power to abolish appeals to the Judicial Committee of the Privy Council ${ }^{32}$, but in essence the subordination of Rhodesia was reduced to the only power Britain never relinquished vis-à-vis Rhodesia. This was the power of the Rhodesian legislature to create its own capacity, that is, to change the legal substance of its subordination to Britain, which was visible only in external affairs ${ }^{33}$ but almost non-existent in domestic affairs.

31 Sir Frank Soskice, the Attorney-General, in the House of Commons on 8 November 1961 (The Times, London, 1961, November 9).

32 The Privy Council is the Queen's own Council, consisting of over 300 distinguished men drawn from all walks of life. Its function is to give private advice to the Queen. From it have sprung many organs of the British political system. For example, the Cabinet was originally a committee of the Privy Council. To-day the Judicial Committee of the Privy Council is a body of distinguished lawyers acting as a court of appeal from the courts of some of the countries of the Commonwealth.

33 In the field of external affairs the authority of Rhodesia had in all cases to be supported by. Britain's consent in the form of an authorisation or entrustment by the United Kingdom government. 
The 1965 Constitution replaced the 1961 Constitution on 11 November 1965, when independence was unilaterally declared. The 1965 Constitution contained provisions purporting to validate the seizure of independence, to remove limitations on Rhodesia's sovereignty and British powers of control, and to substitute a Head of State (designated the "Officer Administering the Government") in place of the Governor and acting for Her Majesty on Rhodesian ministerial advice. In short the Constitution asserted Rhodesian independence and repudiated the British authority ${ }^{34}$.

The 1965 Constitution provides a striking example of the futility of laying down human rights and thereafter subjecting them to the control of a legislature which blatantly contradicts them ${ }^{35}$.

By adopting the Southern Rhodesia Act, 1965'36, the British Parliament declared the 1965 Constitution of Rhodesia and "any act done or instrument made in purported promulgation thereof as void and of no effect". The Act stated that Rhodesia remained part of Her Majesty's Dominions and that the Government and Parliament of the United Kingdom "had the responsibility and jurisdiction hitherto existing in respect of it" ${ }^{37}$. When Mr. Smith's Rhodesian Front government devised the 1965 constitution, they argued that it did not differ in essentials from that of 1961; but it did, and especially in the means of amending it. Under the 1961 Constitution, to amend entrenched clauses (the franchise, the declaration of rights, and African tribal land) a two-thirds majority was needed in the Legislative Assembly (which the white A role seats commanded) and a referendum in which each of the four racial sections of the population voted separately, or a reference by the Governor to the British Government.

The 1965 Constitution requires only the two-thirds majority, repeated twice, which of course Mr. Smith has always had at his command. He used this arrangement quite simply, to bring about a Parliamentary majority for the Constitution Amendment Act of 1966 which introduced much grossly racially discriminatory regulations, as well as a Preventive Detention Act and the easy prolongation of state of emergency legislation which completely abrogates human rights. It also provided a parliamentary majority for the replacement of the 1965 Constitution "legally" by the 1970 Republican Constitution.

\footnotetext{
34 For a legal analysis of the constitutional developments in Rhodesia in general and of the 1965 Constitution in particular, see, Palley, C.: The Constitutional History and Law of Southern Rhodesia 1888-1965, London, 1966.

35 Since the introduction of the 1965 Constitution the regime of the white minority has shown an unmistakable tendency to embark on a discriminatory policy of "apartheid", described by the term "separate development of races". The developments in this direction have been examined in an article entitled "Apartheid in Rhodesia" in the Bulletin of the International Commission of Jurists, Geneva, 1968, No. 33, pp. 21-25.

36 Elizabeth II, Chapter 76.

37 The issue of the "internal de jure status" was raised in a legal battle in the case of Mr. Daniel Madzimbamuto, a detainee in Gwelo prison, that emergency regulations made by the Smith régime in Rhodesia were illegal. The Southern Rhodesian Appeal Court upheld his detention without trial on the grounds that, as the Smith régime was a de facto government, at least those of its acts which were valid under the 1961 Constitution, such as the declaration of a state of emergency and the issuance of regulations thereunder, were entitled to recognition and enforcement by the courts. On 28 July 1968 the Judicial Committee of the Privy Council overruled the decision. On 9 August $1968 \mathrm{Mr}$. Justice Davies ruled in the Salisbury High Court that the illegal régime had now achieved what he described as , internal de jure status” and that the judgement of the Judicial Committee of the Privy Council was not binding on the Court. For a review of the legal developments in Rhodesia since the UDI, see "Special Committee on the Situation with regard to the Implementation of the Declaration on the Granting of Independence to Colonial Countries and People, United Nations General Assembly: Southern Rhodesia" (a working paper prepared by the Secretariat) (Doc. A/AC.109/L. 531 of 20 February 1969).
} 


\section{(d) The Republican Constitution of 1970}

Rhodesia became a Republic on 1 March $1970^{38}$ under a new Constitution which marks the final break with Britain ${ }^{39}$ and whose specially entrenched provisions seek to perpetuate rule by the white minority. The above-mentioned "special entrenched provisions" amply show these rights have been interpreted. Even under the 1965 Constitution, majority rule could conceivably have come about peacefully and even unimpeded, in anything between 35 and 100 years according to one's selection of "ifs". The 1970 Constitution envisages only parity of representation between whites and Africans, and this at an unforeseeable future date by which the Africans will have become far wealthier, and the Constitution will not have been "legally" amended, as it can easily be, to their disadvantage.

African representation is now based of right only on the income tax their community pays, which is at present under one per cent of the total and entitles them to no seats at all. Ex gratia, they start with 16 seats out of sixty-six. Before they are eligible for another seat the African share in income tax payments must become 18/68ths of tax paid, that is over 26 per cent. Obviously this will take a long time to achieve, which is the plain intention behind the decision to base the franchise on income tax (not even on the total contribution to the economy).

\section{Rhodesia's Confrontation with Britain}

The Rhodesian Government has consistently asserted its right to independence from Britain since the beginning of 1963. The dissolution of the Central African Federation in 1963 precipitated the demand. The following is a brief summary of the British-Rhodesian talks prior to the UDI and after it ${ }^{40}$.

1. The first round of exchanges of views on independence was started by a letter of 29 March 1963 from the Prime Minister of Southern Rhodesia, W. J. Field, to

$38 \mathrm{Mr}$. Steward, Secretary of State for Foreign and Commonwealth Affairs, stated in Parliament on 2 March 1970: "The purported assumption of the republican status by the régime in Southern Rhodesia is, like the 1965 Declaration of Independence itself, illegal" (The Times, London, 1970, March 3).

39 The specially entrenched provisions are listed in the Third Schedule of the Constitution (Section 78). They include the provision concerning the constitution of a Senate (23 senators, of whom 10 shall be Europeans, 10 African Chiefs and 3 appointed by the President), the constitution of the House of Assembly (66 members, of whom 50 shall be Europeans and 16 Africans), the Judicature (judicial authority is vested in a High Court of Rhodesia), the requirements of a two-thirds majority for passing a constitutional Bill, the use of English as the only official language of Rhodesia and rights in relation to local authority (Section 86). The Declaration of Rigths (Second Schedule, Section 92) as a whole also falls within the category of specially entrenched provisions, which make the Constitution a modkery of human rights. For example, the first paragraph of the Declaration reads as follows:

"Whereas it is desirable to ensure that every person in Rhodesia enjoys the fundamental rights and freedoms of the individual, that is to say, the right, whatever his race, tribe, political opinions, colour or creed, to life, liberty, security of the person, the enjoyment of property and the protection of the law, and to freedom of conscience, of expression and of assembly and association, and to respect for his private and family life."

(Rhodesia Act No. 54, 1969, to provide for a new constitution for Rhodesia, to provide for the entrenchment of certain provisions of the laws to be enacted relating to electoral matters and land tenure; and to provide for matters incidental to the pregoing (Second Schedule, Section 92).

40 For a detailed account of the negotiations, see "Southern Rhodesia, Documents relating to negotiations between the United Kingdom and Southern Rhodesian Government, November 1963 - November 1965* (Cmnd. 2807, London, HMSO, 1965). For talks after the UDI, see "Rhodesia, Documents Relating to Proposals for a Settlement 1966" (Cmnd. 3171, London, HMSO, 1966). Other documents are "Rhodesia, Report on the Discussions held on board H. M. S. Fearless, October 1968" (Cmnd. 3793, London, HMSO, 1968), "Rhodesia, Report on Exchanges with the Régime since the Talks in Salisbury in November 1968" (Cmnd. 4065, London, HMSO, 1969) and "Southern Rhodesia: Correspondence between Her Majesty's Government and the Government of Southern Rhodesia, April-June 1963" (Cmd. 2073, London, HMSO, 1963). For a detailed account of events as reported in the British and Rhodesian Press and the international press, see "Month-by-month account, from January 1964 to October 1965, of the Rhodesian Government's moves towards a Unilateral Declaration of Independence" in Africa Research Bulletin (London, 1965, p. 10) and a continuation entitled "An impartial and detailed account of the Rhodesian Crisis from December 1965 to January 1967" (London, Africa Research Ltd., 1967, Documentation Service No. 1-2/67, p. 30) A Rhodesian version of the talks is contained, inter alia, in "Statement on Anglo-Rhodesian Relations", December 1966 to May 1969, Salisbury, Prime Minister's Office, 1969 (C. S. R. 36-1969) and in a publication by Peck, A. J. A.: Rhodesia Condemns (Salisbury, 1967, 230 pp.) 
the Secretary of State, R. A. Butler, in which he demanded "in writing from you an acceptable undertaking that Southern Rhodesia will receive its independence concurrently with the date on which either Northern Rhodesia or Nyasaland is allowed to secede, whichever is the first" ${ }^{41}$.

2. A meeting between the Prime Minister of Rhodesia, Ian Smith, and the British Prime Minister, Sir Alec Douglas-Home, took place in September 1964. The communiqué of 11 September 1964 stated that:

The Prime Minister of Southern Rhodesia accepted that independence must be based on general consent and stated that he was convinced that the majority of the population supported his request for independence on the basis of the present Constitution and franchise. The Southern Rhodesia Government recognized that the British Government were entitled to be satisfied about this and Mr. Smith said that he would consider how best it could be demonstrated, so that independence could be granted. The British Prime Minister took note of this statement but said that the British Government had as yet no evidence that this was the case ${ }^{42}$.

3. The visit to Rhodesia by the Commonwealth Secretary, Mr. Bottomley, on 22 February 1964 did not yield any positive results, except for Mr. Bottomley's assurances in Parliament that "he was not without hope that a solution might be found which would command the support of the majority of Rhodesians"43.

4. The London talks between the Prime Ministers of Rhodesia and Britain ended on 9 October 1965, when two separate statements were issued. The British Prime Minister defined the policy of his Government in "five principles" which were as follows:

(i) The principle of unimpeded progress to majority rule, already enshrined in the 1961 Constitution, would have to be maintained and guaranteed.

(ii) There would also have to be guarantees against retrogressive amendment of the Constitution.

(iii) There would have to be immediate improvement in the political status of the African population.

(iv) There would have to be progress towards ending racial discrimination.

(v) The British Government would need to be satisfied that any basis proposed for independence was acceptable to the people of Rhodesia as a whole ${ }^{44}$.

The views of the Rhodesian Government were expressed by Mr. Ian Smith in the following way:

(i) The 1961 Constitution provides, in the qualifications governing the franchise, for an increasing number of Africans to be entitled to vote and the question of guarantees against retrogression is essentially a matter of providing suitable mechanism.

(ii) The Government of Rhodesia proposed the addition of a Senate (to be composed of 12 chiefs elected by the Chiefs' Council) which would vote with the Assembly at third readings on any question affecting the revision of the entrenched clauses. This would replace the referendum procedure under the 1961 Constitution.

(iii) The Government of Rhodesia stated that their proposals for a Senate to be composed of 12 African chiefs represented a major advance for Africans. They could not contemplate any increased representation for Africans in the Assembly while so many Africans rejected the opportunities offered under the present

41 Cmd. 2073 quoted above.

42 "Mr. Smith's illegal declaration", Africa Research Ltd., London, 1965, p. 3.

43 Ibid., p. 5.

44 Ibid., p. 6. 
Constitution, but they were prepared to consider an extension of the B Roll franchise, for example, by admitting to it all taxpayers.

(iv) 'The Government of Rhodesia stated that they wished to see an end to racial discrimination by an evolutionary process, but they could not agree to the repeal of the Land Apportionment Act.

(v) The Government of Rhodesia claimed that they had already demonstrated that the majority of the people of Rhodesia desired independence on the basis of the present Constitution. This had been shown by their consultation of tribal opinion and their referendum on the electorate ${ }^{45}$.

5. The last meeting between the two Prime Ministers before Rhodesia unilaterally declared itself independent was held on 25 October 1965, when the British Prime Minister, Harold Wilson, flew to Salisbury in an attempt to stave off the Declaration of Independence, which by that time had become an imminent threat. $\mathrm{He}$ reached an agreement with the Ian Smith government to set up a Royal Commission presided over by Sir Hugh Beadle, the terms of reference of which were

... to recommend such amendments to the 1961 Rhodesian Constitution as will provide the basis on which Rhodesia may proceed to independence as rapidly as possible in a manner which will give effect to the principles enunciated by the British Government in their statement of 9th October, 1965 , and will be acceptable to the people of Rhodesia as a whole ${ }^{46}$.

The establishment of the Royal Commission, however, did not prevent the Unilateral Declaration of Independence, which was proclaimed on 11 November 1965, before the Commission had even started to work.

6. In pursuance of its intention to restore legality in Rhodesia in order to secure the return of Rhodesia to constitutional rule, the British Prime Minister, Harold Wilson, in his statement of 25 January $1966^{47}$ added a sixth principle to the previous five, on the basis of which settlement with Rhodesia could be achieved. The sixth principle, namely, "the need to ensure that, regardless of race, there was no oppression of majority by minority or of minority by majority"48, thus reiterated the British objective of a just society in Rhodesia based on equality and opportunity. Following an exchange of notes and informal contacts between London and Salisbury, two meetings between the Prime Ministers of Rhodesia and Britain took place:

(a) The first was the meeting (described as a "final effort to secure an honourable settlement") ${ }^{49}$ which took place on board H. M. S. Tiger off Gibraltar between 2 and 5 December 1966. The discussions centered on the issues of a return to legality, the form of an independence constitution based on the six principles and the testing of public opinion under the fifth principle. A working document covering all three major areas of the problems was produced and both sides agreed to notify each other whether the document was acceptable as a basis for a settlement. The British Government published its acceptance of the document on the evening of 4 December, while the Rhodesian Government announced its refusal of the document on 5 December $1966^{50}$.

\footnotetext{
45 Ibid.

46 Cf. Cmnd. 2807, quoted above.

47 Cmnd. 3171 , quoted above.

48 Ibid.

49 Rhodesia, Documents Relating to Proposals for a Settlement 1966, (Cmnd. 3171, London, HMSO, 1966,

50 For the full text of the document, see Cmnd. 3117 quoted supra, pp. $38-83$.
} 
(b) The second meeting between Harold Wilson and Ian Smith took place on board H. M. S. Fearless in Gibraltar from 9 to 13 October 1968. It was described by the British Prime Minister in his statement made in the House of Commons on 15 October 1968 as "hard-hitting exchanges in 30 hours of talks", which, according to him, "confirmed that there was and remains a deep difference between the two sides, not only on the requirements for a settlement, but even more so on the basis of the political philosophies which underlie the attitudes expressed"51.

7. The Conservative Government, led by Edward Heath, which assumed power in Britain following the elections in June 1970 has not yet at the time of the writing of this article disclosed its intentions for a new meeting on a full-scale basis with Rhodesia, although, according to The Times of 6 November 1970, discussions between the British and Rhodesian diplomats in Pretoria are understood to be preparing the ground for such a meeting ${ }^{52}$. There is no doubt that the resolution submitted to the Conservative Party Annual Conference at Blackpool on 9 October 1970 by George Pole, although rejected, must nevertheless have considerably raised Rhodesian hopes, encouraged by the British Government's decision to supply arms to South Africa ${ }^{53}$.

\section{The Organization of African Unity and the Rhodesian Crisis}

Although the confrontation of the world community and Rhodesia took place largely at the United Nations, it is necessary to mention briefly the attitude of Africa's most important international organization. After all, the Rhodesian issue has dominated the agenda of the OAU since 1963, when the Organisation came into existence ${ }^{54}$. Almost every meeting of both the Council of Ministers and the Assembly of Heads of State and Government of the OAU has dealt with the Rhodesian issue ${ }^{55}$. The essential purpose of all the resolutions adopted by the

51 "Rhodesia, Report on the Discussions held on board H. M. S. Fearless, October, 1968" (Cmnd. 3793, London, HMSO, 1968, p. 4). The British proposals for settlement submitted to the Rhodesian Government are reproduced on pp. 7-12.

52 The Times of 10 October 1970, in an article entitled "Early Effort to reach Rhodesia settlement", reported that Sir Alec Douglas-Home had promised the Conservative Party Conference at Blackpool that before long the Government would be approaching Mr. Ian Smith to see whether a basis for negotiation could be found within the framework of the five principles. The sixth principle seemed to have been dropped.

$53 \mathrm{Mr}$. George Pole, of the South Kensington Conservative Association, moved «that this conference calls for the immediate withdrawal of sanctions against Rhodesia and supports the policy of Her Majesty's Government of negotiating with the Rhodesian regime to normalize relations". After the speech by Sir Alec Douglas-Home, the motion was rejected by a large majority ("Call to end Rhodesia sanctions rejected", in The Times, London, 1970, October 9).

54 The resolution on decolonisation adopted at the meeting of the Independent African Heads of State and Government at Addis Ababa in May 1963, together with the Charter of the OAU, warned Britain that Government at Adde Aba in May 1963, together with the Charter of the OAU, warned Britain that
the transfer of power to the settler minority in Rhodesia would amount to a violation of the United
Nations Resolution on Granting Independence to Colonial Countries and People (Res. 1514 [XV]). The resolution also contains a pledge by the independent African States to lend their effective moral and practical support to any legitimate measures for the purpose of recovering such power and restoring it to the African majority. For a more detailed account of the OAU policy, see Gupta, A., "The Rhodesian Crisis and the Organisation of African Unity", International Studies, New Delhi, 1967, vol. 9, No. 1, pp. 55-64, and Cervenka, Z., The Organisation of African Unity and Its Charter, London, 1969, pp. 170-191.

55 The Council of Ministers adopted a resolution on Rhodesia at its meeting in Lagos in February 1964 (CM/Res. 14 [II]), in Cairo in July 1964 (CM/Res. 33 [III]), in Nairobi in February 1965 (CM/Res. 50 [IV]), at the Fifth Extraordinary Session in Lagos in June 1965 (ECM/Res. 11 [V]) and at the Fifth Ordinary Session in Accra in October 1965 (CM/Res. 62 [V]). Four resolutions on Rhodesia were adopted at one of the stormiest meetings of the Council of Ministers convened to deal exclusively with adopted at one of the stormiest meetings of the Council of Ministers convened to deal exclusively with
the Rhodesian crisis after the UDI in Addis Ababa in December 1965 (ECM/Res. 13 [VI], ECM/Res. 14 [VI], ECM/Res. 15 [VI] and ECM/Res. 16 [VI]). Other resolutions on Rhodesia were adopted in the following sequence: in Addis Ababa in March 1966 (CM/Res. 75 [VI]), in Addis Ababa in October 1966 (CM/Res. 78 [VII]) and in March 1967 (CM/Res. 96 [VIII]), in Kinshasa (CM/Res. 108 [IX]), in Addis Ababa in February 1968 (CM/Res. 135 [X]) and in Algiers in September 1968 (CM/Res. 153 [XI]. In February 1969 the Council of Ministers, meeting in Addis Ababa, adopted a Declaration on Decolonization and Apartheid which deals extensively with the Rhodesian problem. In September 1969 the Resolution on Decolonization and Apartheid (CM/Res. 206 [XIII]) was adopted. A resolution dealing exclusively with 
OAU has been to put pressure on the British Government to use force to restore legality in Rhodesia ${ }^{56}$.

There is, of course, a considerable contradiction in the African attitude towards the Rhodesian crisis. On the one hand, they accept the British responsibility for dealing with Rhodesia and support the British claim that Rhodesia is still a colony and the UDI a rebellion in constitutional terms. On the other hand, while Britain understands the return to legality in terms of restoring the 1961 Constitution the Africans regard this Constitution as totally unacceptable and indeed as one of the principal causes of the whole crisis. In this connection it should be pointed out that if Rhodesia had been led to independence by an African majority, there is not the slightest doubt that she would have won recognition as a new State, irrespective of the fact that she was violating her Constitution or defying the colonial authority of the United Kingdom.

While it has become quite clear from all previous negotiations between Rhodesia and Britain that Britain's aim is not to bring about immediate majority rule in Rhodesia ${ }^{57}$ but merely to provide a basis for constitutional talks, the members of the OAU have always refused any other settlement short of the implementation of the principle "one man, one vote". At the ninth session of the OAU Liberation Committee in Dar-es-Salaam on 29 June 1966, its Chairman Oscar Kambona declared that anything short of independence based on majority rule would be unacceptable to Africa. "Once again", he said, "we are calling on Britain, which claims that Rhodesia is her responsibility, to speak to the felons in a language they understand - the language of force. Nothing short of immediate use of force can persuade the vandals in Rhodesia to give up ${ }^{58}$ ".

The growing impatience with Britain has been shown, for example, in one of the recent resolutions adopted by the Council of Ministers in Addis Ababa in March 1970

"condemning the United Kingdom and other imperialist powers who support her in her consistent refusal as the only means to establish legality in Zimbabwe, as well as their complicity in sabotaging the comprehensive mandatory sanctions". ${ }^{30}$

It also calls for the application of Chapter VII of the U.N. Charter which provides for the collective use of force, if economic sanctions fail.

Rhodesia was adopted also at the Council's meeting in Addis Ababa in March 1970. At the following meeting in the same year the Rhodesian problem was raised in the resolution on decolonization (CM/Res. 234 [XV]) and in the Declaration on the OAU Contribution to the Celebration of the 25 th Anniversary of the United Nations, and of the 10th Anniversary of the Declaration of the Granting of Independence to Colonial Countries and Peoples (CM/St. 4 [XV]). The Resolution of the Council of Ministers are always endorsed by the subsequent meeting of the Assembly of Heads of State and Government. Special resolutions on Rhodesia were adopted by the Assembly of Heads of State and Government at the first OAU Conference in 1964 in Cairo (AHG/Res. 9 [I]), and at the second meeting in 1965 in Accra (AHG/Res. 26 [II]).

56 For a consideration of the use of force in Rhodesia by Britain, see Sutcliffe, "The Use of Force in Rhodesia", in Venture, London, 1967, Vol. 19, No. 4, (April), pp. 5-9.

57 During the negotiations with the Rhodesian Government in October 1965, the British Government plainly offered to grant independence before majority rule was actually achieved. In the opinion of the Commonwealth Secretary, A. Bottomley, "this was a very major concession". Mr. Harper, the Minister of Internal Affairs in Rhodesia, replied that "this concession was not new. It had been made not by the present Government but by their Conservative predecessors" ("Southern Rhodesia, Documents relating to the negotiations between the United Kingdom and Southern Rhodesian Governments November 1963 - November 1965", Cmd. 2807, London, HMSO, 1967, p. 75).

58 Africa Research Limited, Documentation Service, No. 1-2/67, London 1967, p. 15.

$59 \mathrm{CM} /$ Res. 207 (XIV). 


\section{Rhodesia at the United Nations}

The U. N. debate on the Unilateral Declaration of Independence by Rhodesia was not the first occasion the United Nations had dealt with the Rhodesian problem $^{60}$, although it was undoubtedly the most dramatic one. By its resolution 2024 (XX) of 11 November 1965, adopted immediately after the Declaration of Independence, the General Assembly

1. Condemned the unilateral declaration of independence made by the racialist minority in Southern Rhodesia;

2. Invited the United Kingdom of Great Britain and Northern Ireland to implement immediately the relevant resolutions adopted by the General Assembly and the Security Council in order to put an end to the rebellion by the unlawful authorities in Southern Rhodesia;

3. Recommended the Security Council to consider the situation as a matter of urgency ${ }^{61}$.

The Security Council at its 1257 th and 1265th meetings, between 12 and 20 November 1965, resumed consideration of the situation in Rhodesia. At its 1258th meeting, on 12 November 1965, the Security Council adopted resolution 216 (1965) by 10 votes to none with 1 abstention (France), the operative paragraphs of which read as follows:

The Security Council 1. Decides to condemn the unilateral declaration of independence made by a racist minority in Southern Rhodesia;

2. Decides to call upon all States not to recognize this illegal racist minority régime in Southern Rhodesia and to refrain from rendering any assistance to this illegal régime.

60 The United Nations' first confrontation with Rhodesia took place in 1961 soon after the Order in Council for the 1961 Constitution was published and following the petition by Joshua Nkomo to the United Nations. The debate, which reached its peak in 1962, concentrated on the issue of whether Southern Rhodesia was a non-self-governing territory in the sense of Article 73 of the United Nations Charter. The General Assembly felt that the 1961 Constitution of Southern Rhodesia was incompatible with the principles the United Nations stood for. So strong was the stand which the African and Asian members of the General Assembly took on the racial policies of the Rhodesian regime that the General Assembly adopted a resolution affirming that "the territory of Southern Rhodesia is a non-selfgoverning territory within the meaning of Chapter XI of the Charter of the United Nations" (Resolu-
tion 1747 [XVI] of June 28, 1962). This view was vehemently contested by the delegation of the United Kingdom on the grounds that "Resolutions of the General Assembly could not confer on a territory a status different from that which it actually possessed". (The U. K. delegate in the Fourth Committee of the GA, Mr. Godber, on 25 October 1962 at the 1360th meeting). The British objections to regarding Southern Rhodesia as a "nonself-governing" territory can be summed up as follows:

1. Since 1923 Southern Rhodesia has had its own Government, legislature and administration as well as an army and police and has enjoyed the rights and privileges under both the 1923 and the 1961 Constitutions to an extent unparalleled in other British non-self-governing territories.

2. Southern Rhodesia had not been included on the list of non-self-governing territories enumerated by the General Assembly in its resolution 68 (I) of 14 December 1946, and its absence had never been questioned until 1962.

3. The British Government was not an "administering authority" in the meaning of Resolution 1747 (XVI), as it had not a hand in the day-to-day administration of Southern Rhodesia, as it had in the normal self-governing territories.

In the view of most of the U. N. Members, however, the self-governing policies of Rhodesia simply did not meet the requirements set forth by Article 73 of the Charter, namely, that "the interests of the inhabitants of these territories are paramount". Cervenka, $Z$.: "The legal effects of non-recognition of Southern Rhodesia's Unilateral Declaration of Independence in International law", in: Casopis pro mezinárodní právo, Praha, 1967, Vol. IX, No. 3, pp. 226-227. Balfour, Campbell: Rhodesien - eine Herausforderung für Großbritannien und die Vereinten Nationen. In: Europa-Archiv, Wien, 1967, Vol. 22., No. 4., pp. 135-144. Cefkin, J. Leo: The Rhodesian question at the United Nations. In: International Organization, Boston, 1968, Vol. 22., No. 3., pp. 649-669.

61 Resolution 2024 (XX) of 11 November 1965 
At its 1265th meeting on 20 November 1965, the Security Council adopted another resolution, stating in clear terms the measures to be taken to restore legality in Rhodesia ${ }^{62}$.

In reply to a note verbale of the Secretary-General of the United Nations drawing the attention of the Member States to the specific obligation in the Security Council Resolution on Rhodesia of 20 November 1965, namely, the obligation of non-recognition and the duty to break off all economic relations with Rhodesia, including an embargo on oil, fifty-eight Staates replied, affirming their intention to comply with the resolution ${ }^{63}$.

The United Nations policy of sanctions on Rhodesia ${ }^{64}$ reached its peak on 28 May 1968, when the Security Council, acting under Chapter VII, Articles 39 and 41 , of the Charter of the United Nations, resolved unanimously to impose

62 The operative paragraphs of the resolution, adopted by 10 votes to none (with France abstaining), read as follows: The Security Council,

1. Determines that the situation resulting from the proclamation of independence by the illegal authorities in Southern Rhodesia is extremely grave, that the Government of the United Kingdom of Great Britain and Northern Ireland should put an end to it and that its continuance in time constitutes a threat to international peace and security;

2. Reaffirms its resolution 216 (1965) of 12 November 1965 and General Assembly resolution 1514 (XV) of 14 December 1960;

3. Condemns the usurpation of power by a racist settler minority in Southern Rhodesia and regards the declaration of independence by it as having no legal validity;

4. Calls upon the Government of the United Kingdom to quell this rebellion of the racist minority;

5. Further calls upon the Government of the United Kingdom to take all other appropriate measures which would prove effective in eliminating the authority of the usurpers and in bringing the minority régime in Southern Rhodesia to an immediate end;

6. Calls upon all States not to recognize this illegal authority and not to entertain any diplomatic or other relations with this illegal authority;

7. Calls upon the Government of the United Kingdom, as the working of the Constitution of 1961 has broken down, to take immediate measures in order to allow the people of Southern Rhodesia to determine their own future consistent with the objectives of General Assembly resolution 1514 (XV);

8. Calls upon all States to refrain from any action which would ass ist and encourage the illegal régime and, in particular, to desist from providing it with arms, equipment and military material, and to do their utmost in order to break all economic relations with Southern Rhodesia, including an embargo on oil and petroleum products;

9. Calls upon the Government of the United Kingdom to enforce urgently and with vigour all the measures it has announced, as well as those mentioned in paragraph 8 above;

10. Calls upon the Organization of African Unity to do all in its power to assist in the implementation of the present resolution, in conformity with Chapter VIII of the Charter of the United Nations;

11. Decides to keep the question under review in order to examine what other measures it may deem necessary to take.

63 For the list of the States, see Mezerik, A. G.: Rhodesia and the United Nations, International Review Service, New York, 1966, pp. 19-21.

64 The economic sanctions against Rhodesia were imposed by the United Kingdom immediately after the UDI. The import of Rhodesian tobacco and sugar was banned and the export-credit guarantees were terminated. However, the embargo on oil was imposed as late as 17 December 1965. The sanctions toughened when at the request of the United Kingdom the Security Council adopted a resolution on 9 April 1966 emphasizing the need for an oil embargo and calling upon the Portuguese Government not to offer its port facilities at Beira for the import of oil for Rhodesia and authorizing Britain to use force, if necessary, to prevent the arrival at Beira of vessels reasonably believed to be carrying oil for Rhodesia (S/RES/221). The second phase of the sanctions policy began after the breakdown of the talks on board H. M. S. Tiger in 1968, when the Security Council adopted Resolution 232 on 16 December 1966, imposing selected mandatory sanctions. For details of the sanctions policies, see Rao, P. Ch.: "The Rhodesian Crisis and the Use of Force", in: Africa Quarterly, New Delhi, 1967, Vol. VI, No. 4, pp. 285-296. Schenck, Dedo von: Das Problem der Beteiligung der Bundesrepublik Deutschland an Sanktionen der Vereinten Nationen, besonders im Falle Rhodesiens. In: Zeitschrift für Ausländisches Sanktionen der Vereinten Nationen, besonders im Falle Rhodesiens. In: Zeitschrift für Ausländisches
Offentliches Recht und Völkerrecht, Stuttgart, 1969, Vol. 29., No. 2., pp. 257-315. Bindschedler, Rudolf L.: Das Problem der Beteiligung der Schweiz an Sanktionen der Vereinigten Nationen, besonders im Falle Rhodesiens. In: Zeitschrift für Ausländisches Ơffentliches Recht und Völkerrecht, Stuttgart, 1968, Vol. 28., No. 1., pp. 1-15. Zemanek, Karl: Das Problem der Beteiligung des immerwährend neutralen Osterreich an Sanktionen der Vereinten Nationen, besonders im Falle Rhodesiens. In: Zeitschrift für Ausländisches Offentliches Recht und Völkerrecht, Stuttgart, 1968, Vol. 28., No. 1., pp. 16-32. Ipsen, Hans Peter: Außenwirtschaft und Außenpolitik. Rechtsgutachten zum Rhodesien-Embargo. Stuttgart usw., 1967. 71 p. (Res publica. Beiträge zum öffentlichen Recht. Bd. 19.) Sutcliffe, Robert Baldwin: Sanctions against Rhodesia. The economic background. London: Africa Bureau 1966. 11 p. Curtin, T. R. C.: Rhodesia under sanctions and "the long haul". In: African Affairs, London, 1968, Vol. 67., No. 267., pp. 100-110. Halderman, John W.: Some legal aspects of sanctions in the Rhodesian case. In: International and Comparative Law Quarterly, London, 1968, Vol. 17., No. 3., pp. 672-705. Curtin, T.: and D. Murray: Economic sanctions and Rhodesia: and examination of the probable effect of sanctions on national and personal incomes in Rhodesia and of the effectiveness of sanctions on Rhodesia policy, London: Institute of Economic Affairs 1967. 56 p. (Institute of African Affairs. Research monograph. 12). Franck, Th. M. (und andere): The legality of mandatory sanctions by the United Nations against Rhodesia. New York: New York Univ., Center for International Studies 1968. 36 p. (Policy Paper. C 1 S No. 1.). 
comprehensive mandatory sanctions on Southern Rhodesia ${ }^{65}$. The resolution proclaimed a virtually complete ban on all trade with Rhodesia, on the supply of funds to that country, and on the maintenance of direct or indirect airline services for Rhodesia by companies established in other states. It also declared Rhodesian passports invalid for international travel.

Under Article 41 of the Charter, the Security Council could have ordered the complete or partial interruption of postal, telegraphic, and radio communications between Rhodesia and other states. That was not done. Otherwise, the Security Council took steps which were just short of military measures. While the greater part of world opinion supported the United Nations measures on Rhodesia, a number of arguments were raised against the lawfulness of the United Nations' action. The basic substantive argument was that the activities of the white regime in Rhodesia could not be appropriately characterized as constituting "a threat to peace" within the meaning of the Charter. The second was based on the presumption that the United Nations' actions were contrary to the principle of domestic jurisdiction and the right of self-determination ${ }^{66}$. The criticism of the lawfulness of the United Nations' actions was perhaps strongest in the United States ${ }^{67}$.

The dissenting voices were fully exploited by the Ian Smith government, which was always at pains to prove the legality of Rhodesia's status as an independent State ${ }^{63}$. The mandatory sanctions, however impressive in terms of the United Nations' Charter, did not bring about the expected economic breakdown of Rhodesia, nor did they make the Smith régime renounce the Declaration of

65 S/RES/253.

66 These and other arguments challenging the legality of the United Nations' actions on Rhodesia have been refuted in one of the best legal analyses of the problem by Professor M. S. McDougal, of the Yale Law School, and Professor W. M. Reismann in their article "Rhodesia and the United Nations: The Lawfulness of International Concern" in the American Journal of International Law, Washington, 1968, Vol. 62, No. 1, pp. 1-19. The authors quote numerous examples of criticism levelled against the United Nations in the American Congress and the American press. The similarity between the racial discrimination practised by the Rhodesian régime and the thinking of the United States Congressmen from the South was indeed striking. Thus, Representative Selden, of Alabama, said: "But what international crime has Rhodesia committed? Whose borders has Rhodesia invaded? What section of the national crime has Rhodesia committed? Whose borders has Rhodesia invaded? What section of the Britain argue that Rhodesia has become a threat to the peace?" (ibid., p. 6)

67 See note, supra. One of the most eloquent advocates of the Rhodesian case in the United States was the former Secretary of State, Dean Acheson, whose letter to the Washington Post of 11 December 1966 became a standard quotation in Rhodesian publication on this subject. Dean Acheson wrote, inter alia:

"Rhodesia's voting laws and system of popular representation in its Legislature are not contrary to any international obligation. The one-man-one-vote deduction from the Fourteenth Amendment is not recognised in international law, as our friend King Feisal of Saudi Arabia can testify. Indeed, the present system in Rhodesia, broadly speaking, has been in effect and regarded with complacency in Great Britain for nearly half a century. This system operates entirely within the boundaries of Rhodesia and affects no-one else. In such a situation, the U. N. Charter is plain. Chapter I, Article 2, paragraph 7 provides unequivocally that the United Nations shall not intervene in matters which are within the internal jurisdiction of any State. The United Nations evades this simple command by reasoning worthy of the Red Queen in Through the Looking Glass. One has to follow it closely. Rhodesia, in doing what the U. N. has no jurisdiction to forbid, annoys African members to the point where they may transgress against the First Commandment of the U. N. (Chapter I, Article 4): "All members shall refrain in their international relations from the threat or use of force against the territorial integrity or political independence of any State.' Since Rhodesia, by doing what it has always done and with which the United Nations cannot constitutionally interfere, incites less law-abiding members to violate their solemn obligation not to use force or the threat of force in their international relations, Rhodesia becomes a threat to the peace and must be coerced."

This argument, however, misses an important point, namely, that the claim of domestic jurisdiction cannot be invoked effectively to excuse the systematic deprivation of human rights in Rhodesia recognized by the Security Council as construction a "threat to the peace", which makes all conceptions of domestic jurisdiction quite irrelevant.

As $\mathrm{far}$ as the claim to the right of self-determination is concerned, by no stretch of imagination can the actions and avowed and executed political programs of the white Rhodesian minority be characterized as genuine Rhodesian self-determination. It would be a travesty of the most basic notion of self-determination to speak of it, in regard to a claim of $6 \%$ of a population against $94 \%$ of the population, when the goal of the claim is to gain absolute political control over the majority and to maintain them in a state of secondary and powerless citizenship (McDougal, and Riesman, op. cit., p. 18).

68 These arguments are summed up in the book by A. J. A. Peck, Rhodesia Condemns, Salisbury, 1967. 
Independence and negotiate a new independence constitution. In that respect the economic sanctions completely failed ${ }^{69}$, the principal reason being that the noncompliance with the U. N. resolutions by South Africa and Portugal, whose trade and economic relations with Rhodesia never ceased and are most unlikely to cease in the future.

The move by the United Nations in reaction to the declaration that Rhodesia was a Republic was initiated by the Afro-Asian states moving a resolution in the Security Council on 17 March 1970, condemning the persistent refusal of the government of the United Kingdom to use force. The resolution was vetoed by the United Kingdom and the United States. Lord Caradon, the British representative, reiterated that there was no question of Britain starting a war in southern Africa, just as there was no question of Britain enforcing sanctions against South Africa ${ }^{70}$.

The last preoccupation of the United Nations was at the plenary session of the General Assembly in November 1970. On November 16, 1970 the Afro-Asian countries moved a strongly worded resolution which summes up the Rhodesian issue and contains suggestions for its solution in the following way:

"The General Assembly ...

Bearing in mind the relevant provisions of its resolution 2621 (XXV) of 2 October 1970 containing the programme of action for the full implementation of the Declaration,

Gravely concerned at the deteriorating situation in Southern Rhodesia, which the Security Council in its resolution 277 (1970) reaffirmed as constituting a threat to international peace and security, resulting from the introduction by the illegal racist minority régime of new measures, including the purported assumption of republican status, for the purpose of entrenching itself as well as repressing the African people in violation of General Assembly resolution $1514(\mathrm{XV})$, and at the continued presence of South African forces in the Territory, which poses a threat to the sovereignty and territorial integrity of neighbouring African States,

Noting with deep regret that the sanctions adopted by the Security Council have so far failed to put an end to the illegal racist minority régime in Southern Rhodesia, owing primarily to the continued assistance that régime receives from some States, in particular South Africa and Portugal, in violation of Article 25 of the Charter of the United Nations and of the relevant

69 The policy of sanctions of both the United Kingdom and the United Nations was constantly under sharp criticism from the African States, which rightly pointed out that, unless the United Nations was prepared to deal with South Africa and Portugal, they were just "a gigantic miscalculation" (Times of Zambia of 30 March 1967). One of the paradoxes of the sanctions policy was the fact that the country which suffered infinitely more than Rhodesia was Zambia, a country which subscribed to the policy of sanctions at extremely high cost. An excellent appraisal of Zambia's role in this respect is contained in Richard Hall's book, The High Price of Principles (Kaunda and the White South), London, 1969. Sharp criticism of the sanctions also came from Richard Sklar in his paper for the African London, 1969. Sharp criticism of the sanctions also came from Richard Sklar in his paper for the African
Studies Association Annual Meeting at Los Angeles in 1968, entitled "On Returning to the Road of Legality in Rhodesia". A detailed survey of the effects of sanctions on Rhodesia is beyond the scope of this article. For a general consideration of the issue, see, for example, Galtung, "On the Effects of International Economic Sanctions, with Examples from the Case of Rhodesia" in World Politics, New York, 1967, Vol. 19, No. 3, pp. 378-416, and for more recent account of the effect of the sanctions see McKinnell, R.: "Sanctions and the Rhodesian Economy" in The Journal of Modern African Studies, London, 1969, Vol. 4, pp. 559-581; Haddon, E.: "Rhodesia's Four Years of Sanctions" in Africa Contemporary Record, 1969-70, edited by. Colin Legum and John Drysdale, Africa Research Ltd., Exeter, 1970, pp. A 1 - A 11, and Colin Legum "UDI - Five Years On", in New World, London, 1970 (November). Röhrich, Wilfried: Das umstrittene Experiment Rhodesien.' In: Außenpolitik. Zeitschrift für internationale Fragen, Freiburg, 1969, Vol. 20., No. 2., pp. 99-106. Die Rhodesien-Frage. Historischer und verfassungsrechtlicher Hintergrund. Konsequenzen der illegalen Unabhängigkeitserklärung. In: Britischen Nachrichten-Archiv, Bonn, 1967, No. 5., pp. 1-8. Dokumente zur Rhodesien-Krise. In: Europa-Archiv, Wien, 1967, Vol. 22., No. 3., pp. 56-59. Sachs, Emanuel Salomon: Rhodesien. Wilson kapituliert vor den Rassisten. In: Blätter für Deutsche und Internationale Politik, Köln, 1969, Vol. 14., No. 6., pp. 646-659.

70 The Economist of 21 March 1970 commented on the event in the following way: “This much must be well known to all delegates to the United Nations. Britain to-day has neither the will nor the ability to bring down the government of Mr. Ian Smith, and force has long since been ruled out by Mr. Wilson. It is also quite unrealistic to expect Britain to stop trading with South Africa and Portugal.” 
resolutions of the General Assembly and the Security Council,

Reaffirming its conviction that the sanctions will not put an end to the illegal racist minority régime in Southern Rhodesia unless they are comprehensive, mandatory, effectively supervised, enforced and complied with, particularly by South Africa and Portugal,

Bearing in mind that the Government of the United Kingdom of Great Britain and Northern Ireland, as the administering Power, has the primary responsibility for putting an end to the illegal racist minority régime in Southern Rhodesia and for transferring effective power to the people of Zimbabwe on the basis of majority rule,

1. Reaffirms that inalienable right of the people of Zimbabwe to freedom and independence in conformity with the provisions of General Assembly resolution $1514(\mathrm{XV})$ and the legitimacy of their struggle to attain that right by all the means at their disposal;

2. Declares illegal all measures taken by the racist minority régime, including the purported assumption of republican status, to deprive the people of Zimbabwe of their legitimate rights and to entrench its policies of apartheid in Southern Rhodesia;

3. Affirms that any attempt to negotiate the future of Zimbabwe with the illegal racist minority regime would be contrary to the provisions of resolution $1514(\mathrm{XV})$;

4. Condemns the failure and refusal of the Government of the United Kingdom of Great Britain and Northern Ireland to take effective measures to bring down the illegal racist minority régime in Southern Rhodesia and to transfer power to the people of Zimbabwe on the basis of majority rule, in accordance with the relevant resolutions of the General Assembly, and calls upon that Government to take such measures without further delay in fulfilment of its responsibility as the administering Power;

5. Condemns the intervention of South African armed forces in Southern Rhodesia in violation of Security Council resolution 277 (1970);

6. Condemns the policies of the Governments of South Africa and Portugal and other Governments that continue to maintain political, economic, military and other relations with the illegal racist minority régime in Southern Rhodesia in contravention of the relevant United Nations resolutions, thus violating their obligations under the Charter of the United Nations, and calls upon those Governments to discontinue all such relations;

The resolution further

Calls upon all States, specialized agencies and other international organizations concerned, in co-operation with the Organization of African Unity, to extend all moral and material assistance to the national liberation movements of Zimbabwe;

Finally, it draws the attention of the Security Council to the urgent necessity of applying the following measures envisaged under Chapter VII of the Charter:

(a). Widening the scope of the sanctions against the illegal racist minority régime to include all the measures laid down in Article 51 of the Charter;

(b) Imposing sanctions against South Africa and Portugal, whose Governments have blatantly refused to carry out the mandatory decisions of the Security Councili1.

In the opinion of the present author a relaxation or even an abandonment of sanctions on the grounds that they alone cannot topple Ian Smith's régime would amount to the acknowledgment of its victory. More vigorous application

\footnotetext{
71 The resolution was adopted by the General Assembly on December 10, 1970 (A/RES 2652). A considerably less strongly worded resolution was earlier adopted by the Security Council on November 17, 1970 (S/RES/288 [1970]).
} 
rather than relaxation should remain the primary objective of the United Nations policy on Rhodesia ${ }^{72}$.

\section{Conclusions}

In determining Rhodesia's position within the international community, the following factors have to be taken into consideration:

1. Rhodesia has not yet been recognized as a state by any state in the world. It should be emphasized, however, that recognition alone would not in any way alter the basic premise on which the Security Council resolution 217 of 20 November 1965 laid down the obligation of non-recognition ${ }^{73}$.

In this respect the policy of non-recognition has fulfilled an important function in the maintenance of the authority of international law. The obligation of nonrecognition, coupled with the mandatory sanctions imposed on Rhodesia, is of a punitive and coercive character, and its aim is to force Rhodesia to comply with international standards of conduct, as laid down in the Charter and affirmed in subsequent instruments adopted under the auspices of the United Nations in furtherance of the policy of fundamental human rights, namely, the right of selfdetermination and non-discrimination ${ }^{74}$.

The United Nations General Assembly and the Security Council decided, acting in conformity with the procedures laid down by the U. N. Charter, not to recognize the régime in Rhodesia as a state until it complies with the internal and external demands for majority rule and conformity to the principle of basic human rights and other principles of international law. The significance of the Security

72 Colin Legum in his above-quoted article "UDI - Five Years On" convincingly argues that the economic sanctions have been the only means of maintaining Rhodesia's diplomatic isolation, which is essential to keep the rebels from consolidating themselves in power. In his words: "A great deal of nonsense has been spoken about sanctions in the past; this has helped to obscure their real value. Sanctions, as conceived by Mr. Wilson, could never 'topple Smith', but they could - and they have denied him victory. They have been the only means of maintaining Rhodesia's diplomatic isolation, which is essential to keep the rebels from consolidating themselves in power."

73 The construction of the policy of non-recognition is based on the view that acts contrary to International Law are invalid and cannot become a source of legal rights for the wrongdoer. It is to express moral disapproval, manifested in the continued denial of legal title, regardless of the apparent success achieved by the conduct regarded as unlawful, as well as to exercise pressure on the wrongdoer in consequence of such disadvantages as normally follow from the absence of non-recognition. (Lauterpacht, H.: Recognition in International Law, London, 1948, p. 28). As it was put by Oppenheim, "the instruH.: Recognition in International Law, London, 1948, p. 28). As it was put by Oppenheim, "the instru-
ment of non-recognition is admittedly an imperfect weapon of enforcement. However, in the absence of regularly functioning machinery for enforcing the law, it must be regarded as a supplementary weapon of considerable legal and moral potency" (Oppenheim, L.: International Law, London, 1955, Vol. I, 8th Ed., p. 145). Recognition is one of the most difficult topics in international law. The legal and political elements cannot be disentangled - when exercising their sovereign right of recognition or witholding the recognition, states are influenced more by political than by legal considerations. What is not always realized, however, is that the legal effects of recognition in international law are very different from the legal effects of recognition in municipal law, or at any rate in English law. When English courts have to decide whether a foreign state or government exists, they regard themselves as bound by Foreign Office certificate, if the certificate says that a foreign government is not recognized by the United Kingdom, then the courts will simply ignore the existence of that government. (Akehurst, M., A Modern Introduction to International Law, London; 1970, p. 76 and 86.) For the legal effects of recognition in other countries see, D. P. O'Connell, International Law, London, 1965, Vol. I, pp. 86-90.

74 The relevant provisions in the Charter are contained, first of all, in the Preamble, which reaffirms "faith in fundamental human rights, in the dignity and worth of the human person, in the equal rights of men and women..." Other provisions are in Articles 1, 55 and 62 and in Chapter IX, entitled "Declaration Regarding Non-self-governing Territories". It is significant that Article 55 expressly links the maintenance of human rights with the "creation of conditions of stability and well-being, which are necessary for peaceful and friendly relations among nations". Other relevant instruments are the Declaration on the Granting of Independence to Colonial Countries and Peoples (General Assembly Resolution 1514. [XV] of December 14, 1960), the Declaration on the Elimination of All Forms of Racial Discrimination (General Assembly Resolution 1904 [XVIII] of November 20, 1963), the International Convenant on Civil and Political Rights (General Assembly Resolution 2200 [XXI] of December 16, 1966) and the Declaration on Principles of International Law concerning Friendly Relations and Co-operation among States in accordance with the Charter of the United Nations (General Assembly Resolution 2625 [XXV] of November 4, 1970 which was adopted at the occasion of the 25th anniversary of the United Nations. 
Council resolution of 20 November 1965 is in its determination that Rhodesia's non-observance of the conditions for the attainment of independence set forth in Article 73 of the U. N. Charter, constitutes a threat to the peace. In view of the mandatory sanctions imposed on Rhodesia by the Security Council resolution S/RES/253 granting of recognition to the very same régime against which the sanctions are directed would be contrary to the provision of Article 2 (5) of the Charter constituting a duty of member States to "refrain from giving assistance to any state against which the United Nations is taking preventive or enforcement action". Under these circumstances there can be little doubt that recognition would be regarded as a kind of "assistance“ to the régime qualified by the Security Council as "illegal".

2. In the opinion of the members of the Organisation of African Unity and of the United Nations, Rhodesia is still a British colony which is at rebellion with the metropolitan power. Hence Britain's primary responsibility for restoring legality in Rhodesia, with the aim of securing a basis for granting independence which meets the requirement of majority rule. Although Britain has always maintained that it is indeed responsible for Rhodesia, it has proved to be incapable of resolving the legal dilemma it has itself created. On the one hand, Britain claims that Rhodesia is still a colony, with sovereign powers resting with Britain but, on the other hand, it refuses to exercise this sovereign authority over Rhodesia on the grounds of the "convention". What Britain has alsways failed to comprehend is that its claim to sovereignty over Rhodesia establishes not only rights but also duties. If the construction that Rhodesia is still a British colony is accepted, then the responsibility for the Rhodesian policy of the oppression of a majority by a minority rests above all with Britain. As a colony, Rhodesia is not a subject of international law. In this respect the British Government has inescapable responsibility for directing its colony towards independence in conformity with the principles recognized in Article 73 of the U. N. Charter, namely, "to ensure, with due respect for the culture of the peoples concerned, their political, economic, social and educational advancement, their just treatment and their protection against abuses".

Britain was given every possible opportunity to use whatever measures it chose to make Rhodesia comply with the obligations of the United Nations Charter, reiterated by the resolutions adopted by both the Security Council and the General Assembly on the issue. Britain's refusal to resort to force would have been justified, if Britain had proposed other measures to bring about the same desired aim. The five years for which the illegal Rhodesian régime has continued to exist are a sufficiently long period to establish that this has not been the case. The question arises, whether Britain's failure to deal with Rhodesia remains an internal matter for Britain or whether, in view of the international concern that the situation in Rhodesia constitutes a threat to the peace, it can be classified as a flouting of its obligation not only as far as Rhodesia is concerned but vis-à-vis the United Nations. The attitude of the world community to Rhodesia, as exemplified by the policy of non-recognition and the mandatory sanctions, is no doubt a positive aspect of the Rhodesian crisis. While the attainment of Independence by the Union of South Africa in 1910, though her racial policy of apartheid had already begun to gain momentum, had passed unnoticed and was regarded as fully compatible with International Law, only fifty-five years later a community which was based on an almost identical racial policy of discrimination and oppres- 
sion was denied admittance to the international community and treated as a wrongdoer. Its negative aspect is reflected by the grim prospects for the solution of the Rhodesian problem. The following three alternatives are open:

1. The first is that the present Conservative Government, headed by Edward Heath, will succeed in finding a settlement to the crisis. Considering the stand made by the Smith régime on the various proposals for settlement in the past, it is inconceivable that Rhodesia would agree to anything which would commit it to majority rule, certainly not "in our lifetime", as it was put by Ian Smith. Any settlement short of introducing majority rule into the Rhodesian constitution, would be totally unacceptable to the independent African States, and notably to Zambia. Unlike Britain, these states cannot come to terms with the white supremacists. They (and especially Zambia) cannot live for years with the Rhodesian borders serving as channels for retaliatory action - economic and military against themselves. They cannot accept any compromise with the Smith régime. And they have made it abundantly clear that they never will. While the British settlement with Rhodesia may lead to the recognition of Rhodesia by Britain and to the lifting of the economic blockade, it will hardly change the attitudes of the African states ${ }^{75}$.

2. The second possibility is that the Rhodesian crisis will be resolved within the context of a general appeasement of independent Africa by South Africa, as proposed by the President of the Ivory Coast, Houphouet Boigny ${ }^{76}$. Any such settlement should it materialize, would undoubtedly include Southern Rhodesia. In view of the sharp division of the OAU members over this move, it is rather a theoretical than a practical possibility.

3. The third, and in the opinion of the present author, the most likely solution will actually be no solution at all. Rhodesia will continue its non-recognized existence, counting on the gradual wearing off of both the political and economic pressure, in particular that of Great Britain and the United States, which were Rhodesia's important trading partners before the .UDI and which Rhodesia still hopes to win back $^{77}$.

None of these alternatives is, of course, capable of removing the tension in southern Africa, which contains all the elements of a violent racial conflict. It has to be borne in mind that by virtue of its existence the OAU is committed to the elimination of all forms of racial discrimination on the African continent by all possible means and, if necessary, by force. The fighting arm of the Organisation of African Unity, the Committee of Liberation, is, of course, still weak and the

75 Legum, C.: “How long can Britain duck Kaunda's challenge?”, in: The Observer, London, 1968, July 21,

$76 \mathrm{M}$. 9 . Houphouet-Boigny has proposed an African summit conference to get other African countries to join him in an attempt to start a dialogue with South Africa. Force would not solve the problem of apartheid, he said. Dr. Muller, the South. African Foreign Minister, commenting on this issue in his speech in Pretoria on 5 November 1970, said that African leaders in the neighbouring countries, as well as farther north, realized that South Africa's intentions were honest and that co-operation with South Africa was indispensable, especially in the fight against Communism and for the sake of the economic welfare of the area as whole (The Times, London, 1970).

77 Rhodesians were encouraged by the American decision to allow 150,000 tons of Rhodesian chrome, blocked in Salisbury since January 1967, into the U.S.A. Before sanctions, the United States depended on Rhodesian chrome for 25 per cent of its total needs. Martin, J.: "Rhodesia thinks economic sanctions will be eased", in: The Observer, London, 1970, June 21. 
operations of the guerillas based in Zambia and Tanzania are still very limited 78 . But there is a likelihood of much more serious attacks once the guerilla operations become really effective. Both the Prime Minister of South Africa, Vorster, and of Rhodesia, Ian Smith, on a number of occasions, publicly warned President Kaunda and President Nyerere that they cannot except impunity if they continued to allow guerillas to operate from their territory. Hence the deepening concern that, as the guerilla struggle proceeds, the white-ruled régimes which are now in much closer alliance to combat these threats, will invade their neighbours in the way (and probably under the same pretext) the Americans invaded Cambodia, thus challenging those African leaders who remain openly committed to the militant policies of the OAU's Liberation Committee ${ }^{79}$.

A large-scale outbreak of racial war, however distant it may seem at present, is no longer a possibility but rather a certainty. President Kenneth Kaunda of Zambia in an interview with Newsweek said:

If things continue on their present course, we are one day going to see bloodshed on a much higher scale than we might see if the British took some sort of police action against Rhodesia to-day. I hate to say it, but I can see not only a racial conflagration, but also an ideological one. And I fear that in the end it's likely to be a fight in which, as in the Vietnam war, the Western Powers will fight alongside the racialists in South Africa against the black people, on the pretext that Communism is coming in.

\footnotetext{
78 In mid-March 1968, African nationalist guerillas were reported to have opened an offensive across the Zambezi River into Rhodesia. In a joint statement issued in Lusaka on 19 March 1968, the Zimbabwe African Peoples' Union (ZAPU) and the South African National Congress (ANC) stated that it was African Peoples' Union (ZAPU) and the South African National Congress (ANC) stated that it was
the freedom fighters of the ZAPUANC alliance who were carrying out the second offensive against the Smith régime, the first being in 1967. On 12 August 1968, the Rhodesian Government issued a communiqué stating that in all operations during 1968 over 100 guerillas had been killed. The Rhodesian security police were assisted by the South African armed forces, which entered Rhodesia about April 1968 and have stayed there, despite the feeble British protest.

79 Cf. Colin Legum, "Black Power v. White in Africa", in New Society, London, 1970, August 6, pp. 242-244.
} 